\title{
Variation of Mixed Banana peel Substrate and Cow Dung in Biogas Pressure as a Learning Source for Renewable Energy Sources
}

\author{
Puspitawati $^{1}$, Riswanto ${ }^{2}$, and Nyoto Suseno ${ }^{3}$ \\ ${ }^{1,2,3}$ Muhammadiyah University Of Metro \\ Jl. Ki Hajar dewantara 15 A Iring Mulyo Kecamatan Metro Timur \\ rumbiariswan@gmail.com
}

\begin{abstract}
The supply of world energy resources is increasingly depleted. The abundance of cow manure and banana peel can cause environmental pollution. It can be used as raw material for biogas because both materials have a high methane gas ratio. This research is an experiment with six variations in the amount of mixture in each experiment. Results of the research on gas pressure and the best biogas production results using 1-litre banana peel substrate and 4-litre cow dung. Data shows that the gas pressure is faster and is greater when the $\mathrm{pH}$ of the mixture is acidic 6.2, the mixture is thick green and has a strong odour. Gas pressure on day 20 is obtained by 106421 Pascal. The average value of the results of the validation of the learning resources of the three aspects of an assessment is $82.3 \%$; it shows that the poster can be used as a learning resource.
\end{abstract}

Keywords: banana peel substrate and cow dung, biogas, renewable energy source

\section{Introduction}

This industrial era 4.0, humans are required to be able to compete in the world of technology in the use and development of modern technology that always develops well from small things to big things, so that future innovations that are useful for life are expected.

Energy is divided into renewable energy and non-renewable energy. Most of the energy that has been used in everyday life is non-renewable energy in the form of fuel oil (BBM) and gas fuel. The world's energy inventories are increasingly depleted because of the need for innovations in developing advanced technology that should meet three aspects, including energy, economics, and ecology [9].

Oil fuels include energy that cannot be renewed because the formation process takes thousands of years. Humans must have the knowledge and ability to be able to use and use the energy in the right way. Alternative energy sources that can be processed in the surrounding environment, namely sun, water, wind, biogas, and others. Biogas is an alternative energy source obtained from the decomposition of organic matter with microorganisms in anaerobic conditions in a reactor. Biogas is a mixture of gases produced by bacteria that occur in materials that can decompose naturally under anaerobic conditions.
Biogas is obtained from the fermentation of organic materials. Methanogenic bacteria are found in organic materials that can produce methane or other gases [1].

Indonesia is one country that has abundant natural resources such as oil, coal, gas, and even extraordinary natural attractions. Unfortunately, Indonesia is still dependent on petroleum energy sources, thus affecting Indonesia's lack of independence in managing resources. Nonrenewable natural resources are expected to run out in the coming decades. Therefore the government is promoting the renewable energy movement. One of the renewable energies initiated by the government is home biogas. The Government's efforts in optimizing its energy resources by making the following policies: Law No. 33 of 2007 concerning energy in article 20 paragraph 4 contains that the provision of new energy and meeting energy needs in meeting people's needs is by finding alternative energy sources as energy substitutes petroleum [2].

Metro Lampung city has good potential in utilizing renewable energy sourced from biogas energy. The biggest potential of biogas material in Metro city to be developed into biogas is cow dung (A1) with a percentage reaching $84 \%$, goat manure (A2) $8 \%$, buffalo dung (A3) $5 \%$ and chicken manure (A4) as much 3\%. As for the potential of 
vegetable biogas (from plants) which has the highest percentage, namely in code B5, namely from rice straw while for other potential 13\% is B3 (tofu waste) as much as $38 \%$ and B4 (banana peel) by $8 \%$ [3].

\section{Theory}

Organic matter can affect the biogas microorganism process. For example, water hyacinth can play a role in accelerating the process of biogas formation. The treatment of adding water hyacinth mixture to cow dung can accelerate the process of fermentation in biogas. This is evidenced based on data that on the first day the water hyacinth mixture showed changes in biogas pressure of $179.805 \mathrm{~N} / \mathrm{m} 2$, whereas when compared with preliminary test data which only used cattle filth, the pressure change occurred on day 2 with a pressure value of $9,81 \mathrm{~N} / \mathrm{m} 2$ [10]. Biogas composition and variation in three different biogas production plants were studied to provide information pertaining to its potential use as biofuel. Methane, carbon dioxide, oxygen, nitrogen, volatile organic compounds (VOCs) and sulphur compounds were measured in samples of biogases from a landfill, sewage treatment plant sludge digester and farm biogas plant. Methane content ranged from $48 \%$ to $65 \%$, carbon dioxide from $36 \%$ to $41 \%$ and nitrogen from $<1 \%$ to $17 \%$ [11].

The other organic material which is quite abundant is banana peel. Banana skin contains $68.90 \%$ water and $18.50 \%$ carbohydrate. Most of the banana peel waste is still underutilized [4]. A small portion of banana peel waste is usually used for animal feed, and the rest is not utilized.

The role of banana skin substrate in biogas production is to accelerate the reaction of methanogenic bacteria so that it can produce biogas faster. Addition of banana skin substrate to livestock faeces in methanogenic fermentation can increase enzyme activity, but negatively affects VFA amount of biogas production, methane gas content and methane gas production $(\mathrm{CH} 4)$ [5].

Mixing banana skin substrate with cow dung is one way to increase carbon and nitrogen ratio. Addition of a mixture of banana peels to cow faeces by 15 and $30 \%$ has not reached an optimal balance of the carbon and nitrogen ratio, the optimal balance of the carbon and nitrogen ratio in biogas production is in the range of carbon and nitrogen ratio 25 to 30 [5].

Most of the biogas in Metro City is biogas whose raw materials are only livestock manure both duck manure, chicken manure, cow dung, and others. Cows are one of the livestock that is maintained by many people around the Metro. Cow manure is usually used as compost. Excessive and untapped cow dung waste will hurt the environment such as soil, water, air pollution and the spread of infectious diseases. The content of carbon and nitrogen ratio of cow manure is around 24. High carbon and nitrogen ratio will accelerate methane bacteria to react. Therefore cow dung has considerable potential if used as material for producing biogas [1]. Anaerobic digestion of animal manure and slurries offers several benefits by improving their fertilizer qualities, reducing odors and pathogens and producing a renewable fuel - the biogas [12].

The experiment the researchers had done was by making biogas from cow dung; the experimental results were that cow dung produced gas pressure. This research is an experimental study which aims: 1). To determine the effect of variations in the mixture of banana skin substrate and cow dung on the biogas pressure produced. 2). To produce appropriate learning resources, it is necessary to research biogas as an alternative energy source for renewable energy source material. 3). The community can respond well to the research poster

\section{Methodology}

This study uses an experimental method that is by varying the mixture of banana skin substrate to be used with cow dung. Variation of the mixture of banana skin substrate and cow dung. The experiment was carried out 6 times with the number of mixtures in the first experiment namely banana skin substrate 0 litres and 5 litres of cow manure, the second experiment using 1 litre banana peel substrate and 4 litre cow manure, the third experiment used a 2 liter banana skin substrate and dirt 3 liters of cattle, the fourth experiment uses a 2.5 liter banana peel substrate and 2.5 liters of cow dung, the fifth experiment uses a 3 liter banana peel substrate and 2 liters of cow dung, and the sixth trial uses a 5 litre banana peel substrate and 0 litre cow manure.

The process of taking biogas data is carried out in Pekalongan, East Lampung. In addition to biogas pressure, other parameters observed from the results of the study are $\mathrm{pH}$, temperature, mix colour, odour, and air humidity. The testing process is carried out to obtain data by noting the gas pressure changes printed on the manometer. Data collection was carried out for 20 consecutive days from the first day, the second day, the third day, the 4th day, the 5 th day, until the 20th day. The results of this study are learning resources in the form of posters that are useful for reference as well as information in finding alternative energy sources. 
Learning resources are learning media [8]. The feasibility percentage scale, as shown in table 1 .

\begin{tabular}{ccc}
\multicolumn{3}{c}{ Table 1. Category Percentage Scale } \\
\hline No & $\begin{array}{c}\text { Percentage } \\
\text { Scale (\%) }\end{array}$ & Interpretation \\
\hline 1 & $81-100 \%$ & Very Worthy \\
\hline 2 & $61-80,9 \%$ & Worthy \\
\hline 3 & $41-60,9 \%$ & Enough \\
\hline 4 & $21-40,9 \%$ & Not feasible \\
\hline 5 & $0,0-20,9 \%$ & Very inappropriate \\
\hline
\end{tabular}

Learning resources are said to be feasible if the percentage of the feasibility of learning resources is $61 \%$. But not all learning media can function as learning resources. Learning resources generated in this study are poster resources. Learning resources that have been made will be validated by several experts in terms of material coverage, graphics, and complexity. This validation aims to find out that the learning resources (posters) are feasible or not yet to be used or publicized. Tabulation of data is used to calculate the percentage of average rating scores obtained using the formula [6]:

Information:

$$
P_{s}=\frac{S}{N} \times 100 \%
$$

$P_{S}$ : Percentage sub variable

$S$ : Sub variable total

$N$ : maximum total score

Criteria for percentage assessment and interpretation to find out the feasibility of learning resources as a reference for evaluating the data generated from the validator are in table 1 .

\section{Results and Discussion}

The experiments were carried out in 6 variations with a mixture of different ingredients. Experiment 1 used cow dung and trials 2 to 5 used variations of the mixture of banana skin substrate with cow dung and experiment 6 only used a banana skin substrate. All experiments use an additional 5 litres of water, with the results, as shown in figure 1.

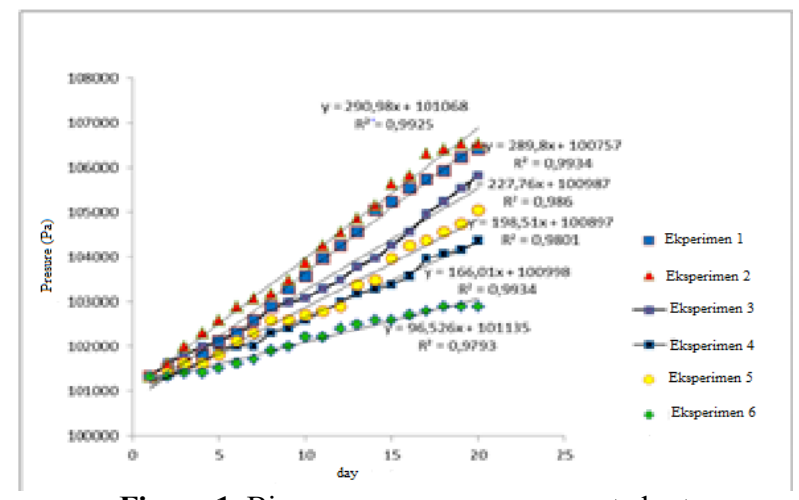

Figure 1. Biogas pressure measurement chart

Results of the study, the amount of biogas pressure produced by the mixture with the volume of cow manure more than the volume of the substrate will produce greater biogas pressure. The fastest rising biogas pressure is found in experiment 2 with a variation of 1-liter substrate and 4-litre cow manure.

Figure 1 graph shows the results of biogas pressure measurements. The highest increase in biogas pressure was obtained from experiment 2 with a mixture of 1-liter substrate, 4-litre cow manure, and 5-litre water. The amount of biogas pressure on day 20 is $106519 \mathrm{~Pa}$. The lowest biogas pressure was found in experiment 4 with 2.5-litre substrate mixture, 2.5-litre cow manure and 5-litre water with $104363 \mathrm{~Pa}$ biogas pressure.

Mixing water hyacinth with cow manure, biogas pressure changes happen on day 1 with the characteristic graph of a $\mathrm{R}^{2}=0.976$. This condition describes that the mixing of the water hyacinth and cow dung provides distinctions signifikant in accelerating the process of occurrence of biogas [13]. While for The effect of mixing banana skin substrate and dirt on biogas pressure will increase biogas pressure faster when the banana skin substrate volume is less than cow dung. The jump in biogas pressure on average occurs on day 14 and day 15 . The jump illustrates the highest increase in biogas pressure from each experiment. The jump in biogas pressure is caused by an increase in reactions caused by microbes, so ideally, an increase in biogas pressure occurs on day 14 and day 15 .

During the fermentation process, air temperature and humidity do not affect the increase in biogas pressure because the increase or decrease in temperature and humidity are not far from the first day and the next day. The average increase in temperature and humidity is stable around $280 \mathrm{C}$ and $74 \%$ air humidity.

The best biogas methane content is when conditioned $\mathrm{pH} 7.0$ [7]. While the results of the research conducted show that the best $\mathrm{pH}$ to produce methane biogas is 6.2 , this is because the highest 
rate of increase in biogas pressure is produced in a comparison of the mixture of banana peel substrate and contaminated with 1: 4 . If the volume of cow manure increases, the $\mathrm{pH}$ value will be higher, and vice versa, if the cow manure is used less, then the $\mathrm{pH}$ value, will be lower.

Meanwhile, the Learning Source Validation results in the form of posters which contain aspects of material coverage, aspects of graphics, and aspects of reusability. The learning source validation process was carried out by three experts, namely one lecturer one teacher and one community leader.

$\underline{\text { Table 2. Percentage of Average Learning Resource Assessment }}$

\begin{tabular}{lcc}
\hline No & Assessment aspects & Value \\
\hline 1 & $\begin{array}{c}\text { Coverage of teaching } \\
\text { material }\end{array}$ & $82,75 \%$ \\
\hline 2 & Graphics & $79,83 \%$ \\
\hline 3 & Usability & $85,91 \%$ \\
\hline & Average & $82,3 \%$ \\
\hline
\end{tabular}

Based on the table the average percentage of assessment of learning resources shows that from the three aspects of assessment of learning resources, namely aspects of assessment of Usability get a greater value of $85.91 \%$, aspects of material coverage $82.75 \%$ and lowest values found in aspects of graphic learning resources, $79,83 \%$. The results of the assessment obtained from the expert validation sheet are $82.3 \%$. This shows that the percentage scale assessment of learning resources more than 60 with interpretations is very feasible to be used as a source of learning.

\section{Conclusion}

There is an effect of variations in the mixture of banana skin substrate and cow dung on the amount of biogas pressure produced. The biggest biogas pressure is generated from treatment 1, which is a mixture of 1-litre banana peel substrate, 4-litre cow manure, and 5-litre water.

The results of the research made in the form of posters have gone through a validation process and are declared very feasible as a source of learning. The material contained in the poster contained discoveries of alternative energy sources by utilizing additional banana skin substrates to accelerate the biogas production process.

The community responded well to posters made from the results of the research. Suggestion, For the community, the results of this study can be used as a reference for processing and utilizing banana peels as an addition to organic material in the manufacture of biogas using cow dung. For teachers, the learning resources that are made can be used as learning resources for renewable energy sources. This research is the manufacture of sensorbased reactors, efforts to minimize gas leakage from reactor tubes.

\section{Reference}

[1] Wahyuni, Sri. 2008. Biogas. Jakarta: Penebarswadaya

[2] UU No 33 Tahun 2007 tentang energi dalam pasal 20 ayat 4

[3] Riswanto, R. (2017). PEMETAAN POTENSI BIOGAS DI KOTA METRO. Jurnal Pendidikan Fisika, 5(2), 126137.

[4] Setiawati, D. R., Sinaga, A. R., \& Dewi, T. K. (2013). Proses Pembuatan bioetanol dari kulit pisang kepok. Jurnal Teknik Kimia, 19(1).

[5] Triatmojo, S., \& Yusiati, L. M. Pengaruh Penambahan Limbah Kulit Pisang (Musa spp) terhadap Produksi Gas Metan dalam Fermentasi Matanogenik Kotoran Ternak. Buletin Peternakan, 36(2), 87-94.

[6] Arikunto, Suharsimi. 2010. Manajemen Penelitian. Jakarta: Rineka Cipta

[7] Kurniawan, Muhammad Ilham.,Kirom, M. Ramdlan dan Suhendi, Asep. 2017. Pengaruh Nilai Ph Awal terhadap Hasil Produksi Biogas pada Reaktor Anaerob.eProceeding of Engineering. Vol. 4.No. 3.Halaman 39773984.

[8] Asyhar, Rayandra. 2011. KreatifMengembangkan Media Pembelajaran. Jakarta: GaungPersada Press

[9] Kholiq, Imam. 2015. Pemanfaatan Energi Alternatif sebagai Energi Terbarukan untuk Mendukung Substitusi BBM. Jurnal IPTEK. Vol. 19. No. 2. Halaman 75-91

[10] Riswanto, R., \& Sodikin, S. (2019). Pengukuran Tekanan Absolut Biogas Berbahan Campuran Eceng Gondok Dan Kotoran Sapi. Jurnal Pendidikan Fisika dan Teknologi, 5(1), 25-29.

[11] Rasi, S., Veijanen, A., \& Rintala, J. (2007). Trace compounds of biogas from different biogas production plants. Energy, 32(8), 1375-1380.

[12] Holm-Nielsen, J. B., Al Seadi, T., \& Oleskowicz-Popiel, P. (2009). The future of anaerobic digestion and biogas utilization. Bioresource technology, 100(22), 5478-5484. 